\title{
Asymmetric Causality Test for Budget Deficit and Economic Growth: The Case of Turkey
}

\author{
Prof. Dr. Mehmet Mucuk ${ }^{1, *}$, Assoc. Dr. Ceyhun Can Özcan² and Dr. İbrahim Özmen ${ }^{3}$ \\ ${ }^{1}$ Faculty of Economics and Administrative Sciences, Selcuk University, Konya, TURKEY \\ ${ }^{2}$ Faculty of Tourism, Necmettin Erbakan University, Konya, TURKEY \\ ${ }^{3}$ Aksehir Faculty of Economics and Administrative Sciences, Selcuk University, Konya, TURKEY
}

\begin{abstract}
Since the 1980s, neoliberal economic policies have accelerated around the world. The active participation of governments in economic activities began to change. Accordingly, significant shifts have occurred in the composition of public expenditures. In many countries, while investment expenditures decreased proportionally; current expenditures and transfer expenditures increased. However, despite the structural transformation in economic policies, budget deficits remained substantial. Therefore, budget deficits and the effects of these deficits have been constantly discussed in the economic literature. As a result of the EU debt crisis, debates on budget deficits have become one of the main agenda items of many countries, international institutions, and central banks. The negative effects of the deficits which were mainly caused by the financing of consumption expenditures were observed during the crisis. While developed countries can use the budget to support the economic growth process, budget deficits in underdeveloped countries can threaten economic stability. The aim of this study is to test the relationship between budget deficit and economic growth using asymmetric causality approach based on data of the period 1980-2011 for Turkey. According to the findings, contractionary fiscal policies adversely affect economic growth.
\end{abstract}

Keywords: budget deficit; economic growth; debt crisis; asymmetric causality; Turkish economy

\section{Introduction}

Governments spend money to meet social needs and regulate economic activities. The usual source of financing for public expenditures is tax revenues. However, if tax revenues are less than public expenditures, budget deficits arise.

Classical economics assumes that full employment will be achieved in the economy in the absence of state intervention. Therefore, according to the classical economists, the state should have both a balanced and small budget. Because budget deficits disrupt fiscal discipline and monetary 
discipline and cause problems such as inflation and unemployment. As a matter of fact, financing budget deficits with debt creates a crowding-out effect on private sector investments. Monetization, on the other hand, increases the inflation rate by increasing the money supply. All these problems disrupt the growth performance of an economy. Classical economists also oppose the budget surplus. Because budget surplus means that resources remain idle (Şen et al., 2007: 3739).

Until the Great Depression in 1929, the basic assumptions of classical economists were considered as true. Classical economists regarded the Great Depression as a temporary shock and claimed that the market mechanism would solve this problem on its own in a short period of time. They attributed the cause of the crisis to high real wages. And they proposed lowering real wages to overcome the crisis. However, Keynes stated that total demand would decrease if real wages were reduced. And the decrease in total demand deepens the crisis (Alt1ok, 2009: 79).

The Keynesian approach suggests that, unlike classical economics, economies can come to equilibrium at levels of underemployment. If markets are not intervened in such an environment, the economy could be plunged into crisis. The main reason for this problem is the lack of demand. Lack of demand refers to the under-use of resources (Eker et al., 1997: 63-64). The economic recession is the result of insufficient demand. It is necessary to use expansionary fiscal policy to end demand shortages. According to the Keynesian economics, fiscal policy is more effective than monetary policy (Erim, 2007: 198). Keynes acknowledged that money was not neutral and proposed a fiscal policy. Because there is a possibility that monetary policy will be caught in the liquidity trap. In the liquidity trap, however, expansionary fiscal policies do not crowd-out private sector investments. Thus, budget deficits bring about economic growth until full employment is achieved (Küçükkalay, 2010: 315).

Keynesian policies were implemented until the 1970s. However, the stagflation crisis increased the need for different economic models. Thus, the views that adopted a balanced and small budget approach emerged again (Yay, 2001: 130). Indeed, neoliberal approaches have gained momentum throughout the world since the 1980s. However, economic crises, in particular, have kept budget deficits on the agenda. Finally, after the 2008 Crisis and the EU Debt Crisis, many countries have used expansionary monetary and expansionary fiscal policies for growth (Dziemianowicz et al., 2018: 12).

The way to increase social welfare is through economic growth. And economic growth depends on the number of production factors, human capital investments and technological developments (Parasiz, 2003: 11). Budget deficits created to support these elements may have positive effects on growth. In some underdeveloped countries, budget deficits are not a choice but a necessity. Because the private sector does not have the resources to achieve its growth targets. However, the important issue here is the effectiveness and efficiency of public interventions (Gönel, 2010: 221). As a matter of fact, public realization of economic activities that the private sector can do more efficiently or improper financing of public expenditures disrupts the relationship between growth and budget deficits (Bulut, 2002: 66). 
Ricardian Equivalence Hypothesis, on the other hand, assumes that budget deficits do not have an impact on economic growth. This is because of the positive impact of expansionary fiscal policy on growth eliminates the increased savings of the private sector (Briotti, 2005: 9-10). The aim of this study is to investigate the relationship between budget deficit and economic growth in the Turkish economy during the period of 1980 to 2011. For this purpose, the asymmetric causality test is used. The remaining of this study has been organized as follows: Section 2 reviews the literature that examines the relationship between budget deficit and economic growth. Section 3 explains the data, methodology, and empirical findings. Finally section 4 concludes the paper with policy suggestions.

\section{Literature Review}

There are different theoretical approaches regarding the effect of budget deficit on economic growth. The classical approach accepts that the budget deficit will have negative effects on economic growth. However, the Keynesian approach assumes that while the economy is at the level of underemployment, the budget deficit will support economic growth. On the other hand, according to the Ricardian Equivalence Hypothesis, there is no relationship between budget deficit and economic growth. Several studies have been conducted to test which of these theories are valid. The results of the previous researches are mixed. Table 1 shows a literature review of the relationship between budget deficit and economic growth.

Table 1: Literature Review

\begin{tabular}{|c|c|c|c|c|}
\hline Author(s) & Countries & Period & Methodology & Results \\
\hline $\begin{array}{l}\text { Buscemi and } \\
\text { Yallwe (2012) }\end{array}$ & $\begin{array}{l}\text { Emerging Countries } \\
\text { (China, India and } \\
\text { South Africa) }\end{array}$ & 1990-2009 & $\begin{array}{lr}\text { Dynamic } & \text { GMM } \\
\text { Method, Fixed Effect, } \\
\text { Random } \\
\text { Estimation }\end{array}$ & $\begin{array}{l}\text { Fiscal deficit are significant } \\
\text { and positively correlated to } \\
\text { economic growth. }\end{array}$ \\
\hline Maji et al. (2012) & Nigeria & 1970-2009 & Granger Causality & No Causality \\
\hline Samırkaş (2014) & Turkey & 1980-2013 & Granger Causality & No Causality \\
\hline Shihab (2014) & Jordan & 2000-2012 & Granger Causality & $\begin{array}{l}\text { There is a unidirectional } \\
\text { causality from economic } \\
\text { growth to budget deficit. }\end{array}$ \\
\hline Nayab (2015) & Pakistan & 1976-2007 & Granger Causality & No Causality \\
\hline $\begin{array}{l}\text { Arjomand et al. } \\
(2016)\end{array}$ & $\begin{array}{l}10 \quad \text { MENA* }^{*} \\
\text { Countries }\end{array}$ & 2000-2013 & $\begin{array}{l}\text { Fixed Effect, Random } \\
\text { Effect Estimation }\end{array}$ & $\begin{array}{l}\text { Budget deficit are significant } \\
\text { and negatively correlated to } \\
\text { economic growth. }\end{array}$ \\
\hline $\begin{array}{l}\text { Rana and Wahid } \\
\text { (2017) }\end{array}$ & Bangladesh & 1981-2011 & Granger Causality & $\begin{array}{l}\text { There is a unidirectional } \\
\text { causality from budget deficit } \\
\text { to economic growth. }\end{array}$ \\
\hline $\begin{array}{l}\text { Molocwa et al. } \\
(2018)\end{array}$ & $\mathrm{BRICS}^{* *}$ & 1997-2016 & $\begin{array}{l}\text { Panel } \\
\text { Causality }\end{array}$ & $\begin{array}{l}\text { There is a bidirectional } \\
\text { casuality between budget } \\
\text { deficit and economic growth. }\end{array}$ \\
\hline
\end{tabular}




\begin{tabular}{|l|l|l|l|l|}
\hline $\begin{array}{l}\text { Öztürk and Sezen } \\
(2018)\end{array}$ & Turkey & $\begin{array}{l}\text { Variance } \\
\text { Decomposition, } \\
\text { Impulse-Response } \\
\text { Analysis }\end{array}$ & $\begin{array}{l}\text { Budget deficits have a } \\
\text { positive effect on economic } \\
\text { growth in the short term. On } \\
\text { the other hand has a } \\
\text { negative effect in the long } \\
\text { term. }\end{array}$ \\
\hline
\end{tabular}

" Middle East and North Africa ${ }^{* *}$ Brazil, Russia, India, China, Spain

\section{Data, Methodology and Findings}

This study examines the relationship between budget deficits and economic growth for Turkey. Table 2 summarizes the variables to be used in this paper.

Table 2. Data and Sources

\begin{tabular}{|l|l|l|l|}
\hline Variable & Abbreviation & Sample & Source \\
\hline Budget Deficit $^{\mathrm{a}}$ & $\mathrm{Bd}$ & $1980-2011$ & Poula et al. (2013) \\
\hline Growth Rate & $\mathrm{Gr}$ & $1980-2011$ & Poulo et al. (2013) \\
\hline
\end{tabular}

Note: ${ }^{a}$ Calculated by the authors using tax revenue and government expenditures.

In order to determine the causal relationship between the budget deficit and economic growth, the stationarity test was performed first. Stationarity states that the mean, variance, and autocovariance of a variable are constant over time. In this respect, the effects of shocks in stationary series disappear in the short term, but shocks in non-stationary series create lasting effects (Gujarati and Porter, 1999: 713). Thus, series containing unit roots need to be fixed by making them free of the trend (Kennedy, 2006: 355-356). In this study, Fourier-type unit root tests were performed to determine whether the series were stationary or not.

\subsection{Fourier Unit Root Tests}

If the time series show a linear or nonlinear tendency, Fourier-type unit root tests can be used for stationarity testing (Becker et al., 2006: 381-382; Yalçınkaya, 2019: 40). The first of these tests is the Fourier KPSS (FKPSS) test developed by Becker et al. (2006). The FKPSS test is designed to provide the best estimate in cases where structural breaks occur gradually. The most important advantage of the FKPSS test is that it does not require pre-determination of the location, number, and form of breaks in the series (Beşer, 2019: 165). The hypotheses of the test are as follows:

$\mathrm{H}_{0}$ : There is no unit root.

$\mathrm{H}_{1}$ : There is a unit root.

The null hypothesis is rejected if the calculated test statistic is greater than the table's critical value.

The second of the Fourier-type unit root tests is the Fourier ADF (FADF) test developed by Enders and Lee (2012). Enders and Lee (2012) suggest the Dickey-Fuller version of the Fourier unit root tests. This version can be useful in the presence of unknown multiple breaks in a nonlinear form. The hypotheses of the test are as follows:

$\mathrm{H}_{0}$ : There is a unit root. 


\section{icalunme}

$2^{\text {nd }}$ International Conference on Advanced Research in

MUNICH, GERMANY

BUSINESS, MANAGEMENT \& ECONOMICS

$\mathrm{H}_{1}$ : There is no unit root.

If the calculated test statistic is greater than the table critical value as an absolute value, the null hypothesis is rejected.

The third of the Fourier unit root tests were developed by Rodrigues and Taylor (2012).

They apply the flexible Fourier form to the local GLS unit root testing procedure of Elliott, Rothenberg, and Stock (1996) and to compare this with the corresponding DF and LM based unit root tests of Enders and Lee (2009). The hypotheses of the test are as follows:

$\mathrm{H}_{0}$ : There is a unit root.

$\mathrm{H}_{1}$ : There is no unit root.

If the calculated test statistic is greater than the table critical value as an absolute value, the null hypothesis is rejected.

Table 3. The Results of Fourier Unit Root Tests

\begin{tabular}{|c|c|c|c|c|c|c|c|c|c|c|c|c|c|c|c|}
\hline \multirow{3}{*}{$\begin{array}{l}\text { Series } \\
\text { Level }\end{array}$} & \multicolumn{15}{|c|}{ Constant } \\
\hline & \multicolumn{5}{|c|}{$\begin{array}{l}\text { FADF } \\
\text { (Enders and Lee, 2012) }\end{array}$} & \multicolumn{5}{|c|}{$\begin{array}{l}\text { FGLS } \\
\text { (Rodrigues and Taylor, 2012) }\end{array}$} & \multicolumn{5}{|c|}{$\begin{array}{l}\text { FKPSS } \\
\text { (Becker et al., 2006) }\end{array}$} \\
\hline & Stat. & $\mathbf{L}$ & $\mathbf{K}$ & $\% 5$ & $\% 10$ & Stat. & $\mathbf{L}$ & $\mathbf{K}$ & $\% 5$ & $\% 10$ & Stat. & $\mathbf{L}$ & $\mathbf{K}$ & $\% 5$ & $\% 10$ \\
\hline $\mathrm{Gr}$ & $-3.66^{a}$ & 0 & 4 & -2.97 & -2.64 & $-6.06^{\mathrm{a}}$ & 0 & 3 & -2.35 & -2.00 & $0.03^{\mathrm{a}}$ & 0 & 5 & 0.46 & 0.35 \\
\hline \multirow[t]{3}{*}{$\mathrm{Bd}$} & -3.33 & 2 & 1 & -3.81 & -3.49 & $-3.46^{\mathrm{a}}$ & 2 & 1 & -3.29 & -2.32 & 0.19 & 0 & 1 & 0.17 & 0.13 \\
\hline & \multicolumn{15}{|c|}{ Constant and trend } \\
\hline & Stat. & $\mathbf{L}$ & $\mathbf{K}$ & $\% 5$ & $\% 10$ & Stat. & $\mathbf{L}$ & $\mathbf{K}$ & $\% 5$ & $\% 10$ & Stat. & $\mathbf{L}$ & $\mathbf{K}$ & $\% 5$ & $\% 10$ \\
\hline $\mathrm{Gr}$ & $-3.62^{b}$ & 0 & 4 & -3.65 & -3.29 & $-4.16^{\mathrm{b}}$ & 0 & 1 & -4.17 & -3.87 & 0.03 & 0 & 3 & 0.14 & 0.11 \\
\hline $\mathrm{Bd}$ & -3.90 & 2 & 1 & -4.35 & -4.05 & -3.76 & 2 & 1 & -4.17 & -3.87 & $0.09^{\mathrm{a}}$ & 0 & 1 & 0.05 & 0.04 \\
\hline \multirow[t]{2}{*}{$\begin{array}{l}\text { First } \\
\text { Dif. }\end{array}$} & \multicolumn{15}{|c|}{ Constant } \\
\hline & Stat. & $\mathbf{L}$ & $\mathbf{K}$ & $\% 5$ & $\% 10$ & Stat. & $\mathbf{L}$ & $\mathbf{K}$ & $\% 5$ & $\% 10$ & Stat. & $\mathbf{L}$ & $\mathbf{K}$ & $\% 5$ & $\% 10$ \\
\hline$\Delta \mathrm{Gr}$ & $-3.72^{a}$ & 3 & 4 & -2.97 & -2.64 & $-3.74^{\mathrm{a}}$ & 1 & 4 & -2.25 & -1.91 & $0.02^{\mathrm{a}}$ & 0 & 4 & 0.45 & 0.34 \\
\hline \multirow[t]{3}{*}{$\Delta \mathrm{Bd}$} & $-6.11^{\mathrm{a}}$ & 0 & 4 & -2.97 & -2.64 & $-3.93^{\mathrm{a}}$ & 0 & 1 & -3.29 & -2.32 & $0.14^{\mathrm{a}}$ & 0 & 4 & 0.45 & 0.34 \\
\hline & \multicolumn{15}{|c|}{ Constant and trend } \\
\hline & Stat. & $\mathbf{L}$ & $\mathbf{K}$ & $\% 5$ & $\% 10$ & Stat. & $\mathbf{L}$ & $\mathbf{K}$ & $\% 5$ & $\% 10$ & Stat. & $\mathbf{L}$ & $\mathbf{K}$ & $\% 5$ & $\% 10$ \\
\hline$\Delta \mathrm{Gr}$ & $-3.48^{b}$ & 3 & 4 & -3.65 & -3.29 & $-3.90^{\mathrm{a}}$ & 1 & 4 & -3.23 & -2.90 & $0.01^{\mathrm{a}}$ & 0 & 4 & 0.14 & 0.11 \\
\hline$\Delta \mathrm{Bd}$ & $-3.90^{b}$ & 3 & 2 & -4.05 & -3.71 & $-6.49^{a}$ & 0 & 4 & -3.23 & -2.90 & $0.06^{\mathrm{a}}$ & 0 & 4 & 0.14 & 0.11 \\
\hline
\end{tabular}

Notes: The maximum Fourier number is selected as 5. According to the Akaike information criterion, the maximum lag length is 3. The critical values of each test were taken from the table values in the related articles. L: lag length. $K$ : Fourier number. $a$ and $b$ reflect $5 \%$ and $10 \%$ significance levels, respectively. 
According to the results of FADF, FGLS, and FKPSS, the series contains unit root at constant and trend level. On the other hand, when the first differences of the series are taken, both are stationary I (1), that is, they do not include a unit root.

\subsection{Asymetric Causality Test}

The asymmetric causality test developed by Hatemi-J (2012) is based on the causality method developed by Toda and Yamamoto (1995). For causality tests, it is sufficient to know the maximum degree of integration of the series in the model and to determine the model correctly. The methodology proposed by Toda and Yamamoto (1995) can be applied regardless of the order of integration of variables (Hacker and Hatemi-J, 2006: 1493; Toda and Yamamoto, 1995: 233). Differences in the stationarity of the series are also considered in this context. The most important feature of the asymmetric causality test is that the series also provides information about positive and negative shocks regarding the causality relationship. The results of the asymmetric causality test are given in Table 4.

Table 4. The Results of Asymetric Causality Test

\begin{tabular}{|l|l|l|l|l|l|l|}
\hline \multirow{2}{*}{ Hypothesis } & \multirow{2}{*}{ VAR(p) } & \multirow{2}{*}{ MWALD } & Asymptotic chi-sqaure & \multicolumn{3}{|l|}{ Bootstrap Critical Values } \\
\cline { 6 - 8 } & & & p-value & \%1 & \%5 & \% 10 \\
\hline $\mathrm{Bd}^{+}=>\mathrm{Gr}^{+}$ & 2 & 1.202 & 0.548 & 31.913 & 13.073 & 7.624 \\
\hline $\mathrm{Bd}^{+}=>\mathrm{Gr}^{-}$ & 2 & $38.230^{*}$ & 0.000 & 26.657 & 13.498 & 8.579 \\
\hline $\mathrm{Bd}^{-}=>\mathrm{Gr}^{-}$ & 1 & 1.297 & 0.255 & 14.473 & 6.607 & 4.031 \\
\hline $\mathrm{Bd}^{-}=>\mathrm{Gr}^{+}$ & 2 & 0.014 & 0.993 & 30.181 & 12.379 & 7.875 \\
\hline
\end{tabular}

Notes: * Indicates that it is statistically significant at the level of \% 1. VAR(p) shows lag length. One lag was added to the VAR lag length according to Hacker and Hatemi (2006) for T:40.

According to these results, contractionary fiscal policies $\left(\mathrm{Bd}^{+}=>\mathrm{Gr}^{-}\right)$have a negative impact on economic growth.

\section{Conclusion}

Governments spend money to meet social needs and regulate economic activities. The main source of financing for expenditures is tax revenues. However, if tax revenues are less than public expenditures, budget deficits arise. According to classical economists, the intervention of the state in the economy disrupts the balance of full employment. For this reason, classical economists argue that the budget should be balanced and small. Keynes, on the other hand, accepts that economies are stabilized in underemployment. Therefore, Keynesian economics assumes that the full employment balance can be achieved through budget deficits. Ricardian equivalence hypothesis suggests that there is no relationship between budget deficit and economic growth. The aim of this study was to examine the relationship between budget deficit and economic growth using asymmetric causality test for Turkey based on data of the period 1980-2011. The findings showed that contractionary fiscal policies negatively affected economic growth. As a matter of 
fact, Turkey is a developing country. And in developing countries, private sector investments are supported by the state. Therefore, while expansionary fiscal policies support growth, contractionary fiscal policies cause total demand to decline.

\section{References}

[1] Şen, H., Sağbaş İ. and Keskin A. (2007). Bütçe Açıkları ve Açık Finansman Politikası Teori ve Türkiye Uygulamast, Ankara: Orion Kitabevi.

[2] Altıo, M. (2009). Keynes ve Keynesçi Kuramda Kriz ve İktisat Politikası Tartışmalarl, Toplum ve Demokrasi, 3(6-7), 75-102.

[3] Eker, A., Altay A. and Sakal M. (1997). Maliye Politikası (Teori, Illkeler ve Yöntemler), İzmir: Anadolu Matbaasi.

[4] Erim, N. (2007). İktisadi Düşünce Tarihi, Ankara: Palme Yayıncılık.

[5] Küçükkalay, A. M. (2010). İktisadi Düşünce Tarihi. İstanbul: Beta Yayıncılık.

[6] Yay, G. G. (2001). İktisat'ın Dama Taşları Ekoller-Kavramlar-İz Bırakanlar I, İstanbul: İstanbul Üniversitesi İktisat Fakültesi Mezunları Cemiyeti İktisat Dergisi.

[7] Dziemianowicz, R., Kargol-Wasiluk A. and Wildowicz-Giegiel A. (2018). New Fiscal Policy? Lesson from the Crisis. 9th Economics \& Finance Conference, London.

[8] Parası, İ. (2003). Ekonomik Büyüme Teorileri. Bursa: Ekin Kitabevi Yayınları.

[9] Gönel, F. D. (2010). Kalkınma Ekonomisi, Ankara: Efil Yayınevi.

[10] Bulut, C. (2002). Kamu Açıkları Enflasyon, Faiz Oranı ve Döviz Kuru İlişkileri, İstanbul: Der Yayınlar1.

[11] Briotti, M. G. (2005). Economic Reactions to Public Finance Consolidation: A Survey of the Literature, Germany: European Central Bank.

[12] Buscemi, A. and Yallwe, A. H. (2012). "Fiscal Deficit, National Saving and Sustainability of Economic Growth in Emerging Economies: A Dynamic GMM Panel Data Approach", International Journal of Economics and Financial Issues, 2(2), pp. 126-140.

[13] Maji, A, Bagaji A. S. Y., Etila, M. S. and Sule J. G. (2012). "An Investigation of Causal Relationship Between Fiscal Deficits, Economic Growth and Money Supply in Nigeria (19702009)", Canadian Social Science, 8(2), pp. 219-226.

[14] Samirkaş, M. (2014). "Effects of Budget Deficits on Inflation, Economic Growth and Interest Rates: Applications of Turkey in 1980-2013 Period", Journal of Economics and Development Studies, 2(4), pp. 203-210.

[15] Shihab, R. A. (2014). "The Causal Relationship between Fiscal Policy and Economic Growth in Jordan”, International Journal of Business and Social Science, 5(3), pp. 203-208. 
[16] Nayab, H. (2015). "The Relationship Between Budget Deficit and Economic Growth of Pakistan", Journal of Economics and Sustainable Development, 6(11), pp. 85-90.

[17] Arjomand, M., Emami K. and Salimi F. (2016). "Growth and Productivity; The Role of Budget Deficit in the MENA Selected Countries", Procedia Economics and Finance, 36, pp. 345352.

[18] Rana, E. A. and Wahid A. N. M. (2017). "Fiscal Deficit and Economic Growth in Bangladesh: A Time-Series Analysis", The American Economist, 62(1), pp. 31-42.

[19] Molocwa, G., Khamfula Y. and Cheteni P. (2018). "Budget Deficits, Investment and Economic Growth: A Panel Cointegration Approach", Investment Management and Financial Innovations, 15(3), pp. 182-189.

[20] Öztürk, S. and Sezen S. (2018). “Türkiye’de Üçüz Açı ile Ekonomik Büyüme Arasındaki İlişki”, Kafkas Üniversitesi İktisadi ve İdari Bilimler Fakültesi Dergisi, 9(18), pp. 501-522.

[21] Gujarati, N. D. and Porter, C. D. (1999). Temel Ekonometri, İstanbul: Literatür Yayıncılık.

[22] Kennedy, P. (2006). Ekonometri Kllavuzu, Ankara: Gazi Kitabevi.

[23] Becker, R., Enders W. and Lee J. (2006). "A Stationarity Test in the Presence of an Unknown Number of Smooth Breaks", Journal of Time Series Analysis, 27 (3), pp. 381-409.

[24]Yalçınkaya, Ö. (2019). "Türkiye Ekonomisinde Dış Borçların Sürdürülebilirliğinin Analizi: Doğrusal ve Doğrusal Olmayan Birim Kök Testlerinden Kanıtlar (1970-2018)”, Maliye Dergisi, 176, pp. 27-51.

[25] Beşer, N. Ö. (2019). “The Effect of Oil Prices on Foreign Trade Deficit in the Economics of Bulgaria", Theoretical and Applied Economics, vol. XXVI 3(620), pp. 159-170.

[26] Enders, Walter and Lee J. (2012). "The Flexible Fourier Form and Dickey-Fuller Type Unit Root Tests", Economics Letters, 117, pp. 196-199.

[27] Rodrigues, P. M. M. and Taylor, A. M. R. (2012). "The Flexible Fourier Form and Local Generalised Least Squares De-trended Unit Root Tests", Oxford Bulletin of Economics and Statistics,74(5), pp. 736-759.

[28] Elliott, G., Rothenberg T. J. and Stock J. H. (1996). "Efficient Tests for an Autoregressive Unit Root", Econometrica, 64, pp. 813-836.

[29] Enders, W. and Lee J. (2009). The Flexible Fourier Form and Testing for Unit Roots: An Example of the Term Structure of Interest Rates, Working Paper, Department of Economics, Finance and Legal Studies, University of Alabama.

[30] Hatemi, J. A. (2012). "Asymmetric Causality Tests with an Application", Empirical Economics, 43(1), pp. 447-456.

[31] Toda, H. Y. and Yamamoto, T. (1995). "Statistical Inference in Vector Autoregressive with Possibly Integrated Processes”, Journal of Econometrics, 66(1), pp. 225-250. 
[32] Hacker, R. S. and Hatemi J, A. (2006). "Tests for Causality Between Integrated Variables Using Asymptotic and Bootstrap Distributions: Theory and Application", Applied Economics, 38(13), pp. 1489-1500. 